\title{
GERMAN ECONOMIC STRATEGIES FOR BRAZIL: AUTARKY AND EXTENDED ECONOMIC SPACE IN THE 1930s
}

\author{
LUIZ FELIPE BRUZZI CURI \\ Universidade Federal de Minas Gerais ${ }^{\mathrm{a}}$ \\ DANILO BAROLO MARTINS DE LIMA \\ Freie Universität Berlin ${ }^{\mathrm{b}}$ \\ VINÍCIUS BIVAR MARRA PEREIRA \\ Freie Universität Berlin ${ }^{c}$
}

\begin{abstract}
This paper addresses the relationship between the development of the concepts of autarky and "economy of the extended space» in the Germanspeaking world and the framing of economic relations between Germany and Brazil in the 1930s. According to this "autarkic» way of conceiving economics, in order to thrive, an economy has to be autonomous regarding its supply of necessary inputs. Proposals presented in the Annual Reports transmitted to the German Foreign Office by German diplomatic representatives in Brazil encouraged, for example, the negotiation of bilateral trade agreements and the expansion of the Brazilian production of strategic inputs for Germany. The choice of Karl Ritter, an expert in economic matters, as ambassador to Brazil is also representative of this strategy.
\end{abstract}

Keywords: autarky, extended economic space, Germany-Brazil relations, National-Socialist foreign policy, Karl Ritter

JEL Code: B17, N44, N46

\footnotetext{
a Cedeplar. Faculdade de Ciências Econômicas, Universidade Federal de Minas Gerais, luizfelipelfbc@gmail.com

b Friedrich-Meinecke-Institut, danbarml@gmail.com

c Friedrich-Meinecke-Institut, v.bivar@fu-berlin.de
} 


\section{RESUMEN}

Este artículo aborda la relación entre la trayectoria de los conceptos de autarquía y «economía de espacio amplio» en el mundo germánico y la estructuración de las relaciones económicas entre Alemania y Brasil en los años 1930. De acuerdo con la manera autárquica de ver las relaciones económicas internacionales, una economía, para prosperar, debe ser autónoma en lo que respecta a su abastecimiento de insumos esenciales. Las propuestas formuladas en los Informes Anuales enviados por las representaciones diplomáticas alemanas en Brasil al Ministerio de Relaciones Exteriores de Alemania encorajaban, por ejemplo, la negociación de acuerdos bilaterales de comercio y la expansión de la producción brasileña de insumos estratégicos para Alemania. La escoja de Karl Ritter, un especialista en asuntos económicos como embajador en Brasil también es ilustrativa de esta estrategia.

Palabras Claves: autarquía, espacio económico amplio, relaciones Alemania-Brasil, política externa nacional-socialista, Karl Ritter

\section{INTRODUCTION}

In Germany, the Great Depression left a disastrous political, social and economic situation. More than 6 million workers were unemployed and, with the reflux of international (mainly American) credits, beginning in 1928 and worsening after the 1929 crash, trade was also strongly affected. Currency reserves were rapidly depleted, and the unfavourable international scenario hindered a recovery of trade (Mazzucchelli 2009, pp. 167-171). In the context of the Nazi rise to power in the 1930s, elements of previous German traditions of economic discourse were coupled with principles of National Socialist ideology in order to offer "solutions» to the general crisis. In other words, the belief emerged that the crisis would be overcome by a racially purified, strong and self-sufficient nation. It is important to underline that this response to the economic turmoil, which stemmed the crisis while paving the way for dictatorship and war, was not the only one under discussion at this juncture in Germany. Liberal strategies involving the return to the gold standard and the opening of the market, as well as proposals that the state should foster economic activity within a democratic framework were also debated, but became increasingly impracticable as the Nazis amassed power (Gourevitch 1986; Bruzzi Curi and Saes 2015).

This produced the conditions for the thriving of a particular conceptual framework for dealing with international trade, whose origins date back to the Greek notion of autarky, related to the state of self-sufficiency of a 
polis. In $19^{\text {th }}$ century Germany a singular connection was constructed between the inherited idea of autarky and the notion of vital space (Lebensraum). For an economy to achieve autarky (Autarkie), it needed to conquer space, or to build an economy of the extended space (Großraumwirtschaft). It is not disputed that this approach lent itself to appropriation by National Socialist foreign policy, particularly in the framing of the Reich's policy for Eastern Europe, which was one of spatial annexation and direct control (Petzina 1968; Barkai 1977; Teichert 1984; Tribe 1995). Furthermore, it is known that Hjalmar Schachts's 1934 New Plan favoured bilateral trade with South America and that German trade with Brazil increased significantly between 1934 and 1938, as Germany became the leading source of Brazilian imports ${ }^{1}$. However, the eventual connections between this conceptualisation of autarky and the framing of specific economic strategies for Brazil have yet to be investigated by the historiography.

In order to explore these connections, we start from the historical evolution of the concepts of autarky and extended economic space and examine primary texts dating from the late $19^{\text {th }}$ century until the 1930 s, in which these ideas were developed. We then analyse the economic discourse of German diplomats serving in Brazil in the 1930s. The leading German representative in Brazil at this juncture was Karl Ritter (18831968), a high-ranking economic bureaucrat in the German government. After some years of activity in the Reich's Finance Ministry, in 1924 Ritter became Director of Economy and Reparations within the Auswärtiges Amt, the German Foreign Office. In 1936 he took over the Department of Trade Policy, before being transferred to Rio de Janeiro as the German ambassador, an office he held until 1938. From Ritter's own writings, as well as from the Annual Reports transmitted to the Foreign Office by German diplomats in Brazil and other diplomatic sources, it is possible to ascertain that there was an important relationship between the particular development of the concepts of autarky and «economy of the extended space» in the German-speaking world and the way diplomats conceived of the economic relations with Brazil in the 1930s.

To assess the historical development and political implications of the autarkic approach to foreign economic relations we draw upon a specific methodology: the history-of-concepts approach, which identifies the mutual interaction between concepts and the reality of political and social conflicts. According to Koselleck (1989, pp. 112-113), the study of sociopolitical concepts and their meanings may take on a socio-historical status, because the semantic struggle to define social and political positions and, by means of these definitions, to keep or occupy these positions belongs to

\footnotetext{
${ }^{1}$ See Figure 1.
} 
every critical moment in history. In other words, the history-of-concepts method assumes that concepts both register and affect the transformations of governmental, social and economic structures (Richter 1990). This is central to the analysis presented here, as we argue that the referred conceptualisations not only registered specific transformations in the German intellectual and political scene, but they also helped shape the economic strategies envisioned by diplomats dealing directly with GermanBrazilian relations.

The paper is structured as follows. Firstly, we present a history of the aforementioned concepts in Germany, describing their development from the late $19^{\text {th }}$ century until their usage in the 1930s. Secondly, we investigate the role played by Karl Ritter in the elaboration of a project for reestablishing Germany's global commercial position, based on the expansion of the economic space under German influence by means of bilateral trade agreements. Lastly, we examine German diplomatic sources from the period 1928-1938, focusing on the proposals for the Brazilian economy.

\section{THE CONCEPTS AND THEIR HISTORY}

From a history-of-concepts point of view, the image of the nation as a community of coexistence that suffices in itself is representative of the modern content of the term autarky (Rabe 1972, pp. 377ff) ${ }^{2}$. In Germany, this conception of autarkic nation gained significant importance in economics in the second half of the $19^{\text {th }}$ century. Albert Schäffle (1896, pp. 593-594), for example, referred to the people (Volk) as an «autarkic, i.e. self-sufficient, living community of internally and externally coherent human masses». The most sophisticated form of this community was, according to Schäffle, the nation, in its modern, European shape. Historical economists such as Karl Bücher, Gustav Schmoller and, to a certain extent, the state socialist Adolph Wagner adopted this perspective in their theoretical analyses of the "national economy». A common trait of this line of thought was its skepticism towards "Manchesterist» freetrade policies. Within this «national-statist» perspective, as Barkai (1977, pp. 61-62) calls it, there was a tendency to think that national selfsufficiency was to be reached by means of agricultural autarky, as opposed to industrial development (Heilmann 1980, pp. 70-71).

Such agrarianism can be seen as a reaction to the rapid industrial development of Germany in the second half of the $19^{\text {th }}$ century, particularly fostered by the development of railways. The accelerated growth of cities, coupled with the ongoing dissolution of traditional society that threatened

\footnotetext{
2 «Modern» is here in opposition to the ancient (Greek) and medieval notions of autarky. For this previous history of the concept, see Rabe (1972).
} 
the long-established social roles of the peasantry as well as of the landed elites, gave rise to a somewhat nostalgic movement that valued rural life and projected a German agricultural state, even though the course of industrial capitalism was irreversible (Wehler 2008, pp. 618-620). One of the basic arguments was that an industrial society could not develop without a strong and stable agrarian basis. This was illustrated, for example, by Gustav Ruhland's (1894, p. 884) metaphor of the economy as a three-story building, in which the ground floor was agriculture. The first and second levels, corresponding to industry and commerce respectively, would be sustained by columns resting on foreign soil, if German agriculture depended on external supply.

Agrarianism coexisted with industrialist, imperialistic inclinations. In the 1890s, the internal consolidation of the German Reich, politically associated with the prominent role of Chancellor Otto von Bismarck, had been accomplished and the new German Kaiser, Wilhelm II, invested in a more aggressive foreign policy. This new course, the so-called Weltpolitik, envisaged the transformation of Germany into a global power, by means of imperialist colonialism and military development. This spirit was expressed in the famous statement of Foreign Secretary (then Chancellor) Bernhard von Bülow: as a thitherto disadvantaged power, Germany should ambition its "place in the sun» (Mitchell 1999, pp. 23-26). Against this background, the idea of constructing an extended economic space, which secured the inner market for the growing German industry and integrated foreign (colonial) sources of raw materials and agrarian inputs, can be understood as a solution for this supposed antagonism between industry and agriculture.

Attuned with this project was, for example, Gustav Schmoller's proposal to tackle the problem of agricultural constraints by means of the development of a naval fleet and of colonial conquest. To escape the dilemma between "agrarian state» and «industrial state», Germany should not abandon its agriculture, as England had done. It should rather allow industry and trade to expand, which included the eventual conquest of external land for agriculture and the breaking of the commercial monopoly of established world powers. This would be possible, according to Schmoller (1900, pp. 12-20), by means of a strong, competitive navy that would back German merchants. Overseas trade played an important role in his argument; he indicated the necessity of a naval force, in case the Russians stopped delivering grains to the German market.

Theoretically, one of the key steps towards a geographic or spatial conception of autarky that incorporated this expansionist idea seems to have been taken in the 1890s and 1900s by Friedrich Ratzel and his anthropogeographical school (Smith 1980, pp. 54ff), who coined the concept of Lebensraum in its classical form. With a starting point in biology, he defined the «vital space» as the surface area that accommodates a living species, offering conditions for its maintenance and expansion (Ratzel 
1901, p. 115 and 128). The concept comprehended also the human species and, in this case, the unit of analysis was the people or Volk. Human conflicts involving land were naturalised, as they were treated as part of the same general phenomenon of the "domination/occupation of space» (Raumbewältigung) inherent to each living being. So, for instance, Ratzel compared the displacement of Native North Americans by Europeans to the disputes between weed and garden vegetables. Hence, by means of analogies elevated to the status of laws of nature, the idea of human Lebensraum gained an expansionist connotation; like a species of tree or coral, people had to grow and amplify its vital space, or else perish. In practice, for Ratzel human communities should expand their Lebensraum through the conquest of new farming land or, in other words, through colonisation (Ratzel 1901, pp. 155-156 and 170-171).

The spread of this expansionist ideology in Europe was an important factor leading to the outbreak of the First World War. The economic management of this conflict in Germany confirmed that not only could the state manage to procure the economic resources needed to finance war spending, but it could also mobilise enough labour force and material inputs for the industrial production in a war economy. This context in Germany is associated with the policymaking of Walther Rathenau, who coordinated the distribution of raw materials during the war effort. Albeit concerned about Germany's dependency on foreign supplies of raw materials and food, Rathenau (1913, pp. 267-278) overtly criticised the agrarian protectionism that he saw as beneficial only to Prussian landed elites. Overall, his position in the eve of the First World War was that Germany should seek to solve the problem of the scarcity of raw materials by an aggressive, expansive trade policy. This included challenging the North American Monroe doctrine, so as to open South American countries to German colonisation and exports. Nevertheless, Rathenau recognised the difficulties involved in this proposal and emphasised the need to construct a Central European customs union, which would include France and its dependencies, building thus an economic bloc under German leadership (Barkai 1977, p. 76).

In the interwar period, particularly during the crisis of the 1930s, the term autarky became a catchword adopted by economists and publicists in the fields of economic policy and international politics, to offer recipes for an immediate reversal of the dismal conjuncture. According to Hannah Rabe (1972, p. 381), for the $1925-1930$ period it is possible to identify one published book that had Autarkie in its title; in 1930-1935 the number rose to $20^{3}$. In 1932, Werner Sombart published an essay about the future of

${ }^{3}$ Hannah Rabe's source is the Kaysers Bücherverzeichnis, a regularly published list of the books printed in Germany. 
capitalism in which he tried to sketch possible ways out of the ongoing economic crisis and suggested that, as Germany had been forced to start importing products essential for human sustenance, it had lost its independence-it had ceased to be "autarkic, in the simple employment of the word». Therefore, he proposed autarchy, meaning self-government, autonomy, as a goal to be pursued. In practice, this would involve planning international trade (customs unions, bilateral trade, preferential tariffs) and fomenting agriculture in the domestic economy (Sombart 1932, pp. 39-45). The general guideline was to take into account the particular (geographical, economic, cultural) characteristics of each nation or region, in order to frame a purposeful foreign policy (Teichert 1984, p. 94).

This autarkic approach to international economic relations lent itself to appropriation by political actors directly involved in the National Socialist movement. In 1928, Hitler compiled his ideas on foreign policy in a document known as his «Second Book» (Zweites Buch). Written to become the second volume to Mein Kampf, the Zweites Buch contains Hitler's views on Germany's relations with Britain, Russia and the United States as well as his account of the need for an extended living space. Hitler perceived history as a permanent "struggle for the limited means of sustenance», i.e. an inevitable racial competition for resources (Tooze 2006, p. 8). Thus, for him, the goal of foreign policy, as well as that of domestic policy, was to guarantee the primal national need of nourishment. In Hitler's view, however, this could only be achieved through force. Although the Zweites Buch was not published until the 1960s, Hitler conveyed his intentions in speeches after 1928, as we can see in this excerpt from his speech delivered at Düsseldorf's Industrial Club in 1932.

Only when we have modified this fatal evaluation of ourselves will Germany be able to appreciate the political possibilities which, if we look far enough into the future, can place German life once more upon a natural and sustainable basis: either by new living space [Lebensraum] and the development of a great internal market or by the protection of German economic life against the world utilising the collective German power. (...) our primary need is the restoration of a sound national German political body armed to strike (quoted in: Noakes and Pridham 1998, pp. 94-95).

In that same year, Gregor Strasser delivered a speech in the Reichstag (the German parliament) which would be published shortly afterwards with the title of "Wirtschaftliches Sofortprogramm der NSDAP». This emergency economic programme contained the basic ideas that were supposed to guide the Nazi Party during the pre-election campaign. The crux of the proposals for tackling the critical situation of the German economy was the creation of jobs or Arbeitsbeschaffung. Consonant with this overall idea of economic recovery, the programme also contained, in its second part, suggestions of commercial and financial measures to be adopted by 
the elected government. The idea of autarky was the general directive in this topic, as the programme stated that: «We [Germans] have to produce what we are capable of producing. The German people is forced to do this» (NSDAP 1932, p. 17) ${ }^{4}$. The alleged causes for this forced choice were related to the attack on the German economy inflicted by the victorious powers after the First World War and the subsequent decline in exports. The plan recognised, nevertheless, that total autarky was an impossible endeavour, introducing the basic idea underpinning the bilateral trade policy that Hjalmar Schacht would adopt in the New Plan in September 1934 (Barkai 1977, pp. 43-49). Germany should, according to the programme, export to countries willing to accept industrial products in exchange, and particularly to nations outside Europe, with which the German balance of trade was negative.

Therefore, a guideline of National Socialist policy is to cover the German people's needs by its own production as far as possible, securing the amount in excess of domestic production from friendly European states, particularly if they are willing to accept industrial products from Germany as payment. (...) We will primarily reduce imports from those countries from which we imported more than we exported, those with which we had a surplus in imports. According to the official Reich Statistical Office, Germany had a negative balance of payments of about 270 million marks within countries outside Europe during the first quarter of 1932 (NDSAP 1932, pp. 17-18).

Although this Lebensraum conception of autarky gained a lot of ground in Germany in this context, the debate on international trade and foreign policy, among intellectuals as well as policymakers, has never been restricted to this line of thought. Even during the Great Depression there were prominent thinkers who envisaged more economic integration among nations as a possible way out of the downward trend. One example is Franz Eulenburg, a former student of Gustav Schmoller and Karl Bücher, who in 1932 wrote an essay in which he acknowledged important shifts in international trade, but attempted to show how problematic the idea of autarky was, because Germany lacked the resources, capital and purchase power to be isolated from the world. He pointed out that global

\footnotetext{
${ }^{4}$ An English translation of this programme is available online in the «German Propaganda Archive», a website maintained by Randall Bytwerk. The Sofortprogramm was elaborated by Section IV (Economy) of the Reichsorganisationsleitung of the NSDAP. It was a very "unorthodox» programme that included the creation of jobs by means of «deficit spending» as a central tenet of the economic policy proposed to tackle the crisis. The intellectual mentorship of the plan is not clear, but Avraham Barkai (1977, pp. 43-47) presents convincing arguments that it was influenced by the ideas of a group of thinkers called «Reformers», who were convinced that the way out of the crisis would not be overcome by the adoption of traditional, liberal economic policy. They were gathered in the Studiengesellschaft für Geld- und Kreditwirtschaft and their most prominent publicist was Robert Friedländer-Prechtl.
} 
economic integration would grow, in spite of the current disruptions that he deemed temporary (Eulenburg 1932, pp. 45-59). After the seizure of power by the Nazis in 1933, the defence of these liberal points of view was hindered by the policy of Gleichschaltung (coordination or totalisation), which aimed at the complete Nazification of state and society (Evans 2003, p. 386).

Nevertheless, National Socialist opinions concerning international trade and foreign policy were not completely uniform. Teichert (1984, p. 255) identifies at least three approaches to economic foreign policy inside the Nazi party from 1933 on. The first was represented by the «ideologues of anti-Semitism», Richard W. Darré, Walter Köhler and Werner Daitz, who shared Hitler's expansionist aims and fixation with (Eastern) Europe; their concern was to transform the prerequisites of these goals into economic reality. The second group, which included Hermann Göring and Heinrich Hunke, dealt with problems of economic foreign policy from the point of view of a war economy; they acted under military pressure and focused on fast solutions for the problems related to preparation for the war. The third line, more pragmatic and «moderate», included for example Gustav Schlotterer and Walther Funk, who, while accepting the idea of Germany as a world power in need of military expansion, tried to take into account the specific interests of large industry and of the middle classes. Common to these different inclinations was an evaluation of all foreign economies in terms of their raw materials and patterns of production and consumption. Economic activity was associated with economic space, with the resources physically present in each economic space; precisely the association implied by the idea of Lebensraum.

Accordingly, in this perspective, international trade became a means of conquering more resources, an instrument of domestic expansion, and not, as the free-trade doctrine postulated, a way for the countries involved to achieve mutual benefits. This paved the way for a policy of stockpiling, import substitution and bilateral agreements. From the point of view of classical economic theory, of course, this sort of policymaking involved inefficiencies and hindrances to growth. Yet the world was at a critical conjuncture; international trade was declining, free trade was giving way to other arrangements that bypassed the usage of strong currencies and liberal ideology in general was in crisis (Tribe 1995, pp. 248-249). All this made this approach seem ideologically and practically adequate, even though it contained the somehow paradoxical aspect that a search for autarky went hand in hand with the encouragement (and control) of trade, as expressed for example in Hjamar Schacht's «New Plan» of 1934, which favoured bilateral trade with South America and Eastern Europe (Petzina 1968, pp. 18-19). In a newspaper article written in the same year, Heinrich Hunke attempted to come to terms with this ambiguity and made an insightful statement: 
Autarky has never been for us the contrary of foreign trade. We have always been adversaries of autarky, in the sense of insularity. But we have always considered absolutely necessary that the psychological and practical priority of our people's economy be located in our own space; that the sustenance of our people be secured within their own borders; and that the necessary means of subsistence and raw materials not available in our country, because our natural resources or farming surface are not enough, be purchased preferably in places where they remain within the range of our own weapons in case of instabilities. We are not making a case for an impossible insularity, but for an autarky in the sense of planned imports, managed from the point of view of our own security. Of course, the word autarky is ambiguous. We do not see any reason to change this designation now, after having struggled for it over years. Concepts can change their meaning, but political movements must avoid acting as if they were changing their aims (Hunke 1934, p. 482).

Hunke's «confession» that concepts might change their meaning reveals the peculiar role played by the concept of autarky in this critical context of the 1930s. Connected with the idea that it was necessary to expand Germany's Lebensraum and establish an extended, secure economic space, it drifted from the original meaning of national sufficiency and acquired this expansionist connotation. The role of South American countries in this antiliberal framework of economic thinking was conceived in terms of a commercial expansionism that should serve the autarkic purpose of building a broad and secure network of suppliers to the German economy. It is indeed enriching to examine Brazil's place in German economic strategies of foreign policy in the 1930s against this conceptual background.

\section{GERMAN-BRAZILIAN TRADE RELATIONS: THE ROLE OF KARL RITTER}

In order to understand how this extended concept of autarky, as described by Hunke, was operated by the German foreign policy apparatus and incorporated into German trade relations with Brazil, it is interesting to examine the role played by German diplomat Karl Ritter, an early advocate for the building of stronger ties with South America, and Brazil in particular. Already in 1934, he began to correspond with Arthur Schmidt-Elskop, German representative in Brazil at the time, regarding the possibility of expanding German-Brazilian trade beyond coffee 
beans $^{5}$. As described by Seitenfus (2000, p. 37-38), Ritter saw in the strengthening of German commercial ties with Brazil an opportunity for acquiring the raw materials Germany required to set in motion its rearmament policies.

Ritter was an experienced official in the field of economics. Although he never completed a degree in this field, he began his career in the economics department of the Cologne Newspaper (Kölnische Zeitung). He later held posts in the Reich Colonial Office, the Reich Office for the Interior and the Reich Economic Office, before joining the Reich Finance Ministry in 1919, always handling economic affairs ${ }^{6}$. Among the topics Ritter dealt with during his career were currency, credit and the bank system, as well as food and raw materials. After the end of the First World War, Ritter was entrusted with the task of dealing with the issue of reparations within the Finance Ministry. His new role as head of division (Referent) for the question of reparations helped boost Ritter's reputation as an expert in economic affairs leading to his transfer to the German Foreign Office in 1922 as it took over the reparations negotiations. According to Ritter's defence during the Nuremberg trials, this moment represented the zenith of his career as a civil servant ${ }^{7}$. He was indeed incorporated into the inner circle of Foreign Minister Gustav Stresemann during the Weimar period and played a crucial role in the inter-ministerial talks on international trade and reparations after 1925 (Krüger 1984, pp. 148-149).

Like many of his colleagues in the Foreign Office, Ritter had to navigate the transitions from the Weimar Republic to the Third Reich. Hitler's distrust of traditional elites, which he associated above all with diplomats and the higher echelons of the military, allowed for the emergence of various agencies and departments which, throughout the 1930s, sought to replace or take control of the Foreign Office and the foreign policy apparatus. Many preexisting organisations within the German state were Nazified and others that belonged to the party were incorporated into the state. Notorious examples include the Ribbentrop Office (Dienststelle Ribbentrop) and the Foreign Organization (Auslandsorganisation) which disputed the decision-making power on foreign policy matters in the Third Reich not only with the Foreign Office but also among themselves (Jacobsen and Smith 2012, p. vii). While the Foreign Office was no longer the hegemon in the new Nazi foreign policy environment, its network of embassies, consulates and legations remained an important tool in the

\footnotetext{
5 Anschluss an Telegramm Nr. 38. PAAA R 105.852. Oct. 20, 1934.

6 International Military Tribunal: IMT. Trials of War Criminals: the ministries case, vol. XIII. Nuremberg: 1946-1948. p. 18.

7 International Military Tribunal: IMT. Trials of War Criminals: the ministries case, vol. XII. Nuremberg: 1946-1948. p. 285.
} 
pursuit of Nazi foreign policy goals, including those related to trade. The impact of the Great Depression and the need for the reestablishment of employment had raised economic concerns as priorities, also in the realm of foreign affairs (Tooze 2006, p. 25). This moment coincided with Ritter's resurgence as an important figure in the Foreign Office.

Following the enactment of the New Plan (1934) conceived by Finance Minister Hjalmar Schacht, the Foreign Office set in motion a commercial offensive to sign new trade agreements and review existing ones, to incorporate clearing clauses supposed to halt the currency outflow that was draining Germany of its reserves. Ritter played an important role in this process. He perceived a complementarity between Germany's need for raw materials to be used in the rearmament efforts and the necessities of countries such as Brazil, which were industrialising their economies, but still depended highly on the export of raw materials to finance this process (Seitenfus 2000, p. 37).

In the 1930s, Brazilian foreign trade relied mostly on the export of coffee beans. When prices plunged with the impact of the Great Depression, Brazil was forced to diversify its economy, which meant substituting imported manufactured goods with local products and expanding alternative cultures, such as cotton. The retreat of the United States from international trade also prompted the Brazilian government to look for new trade partners. Ritter seized this opportunity to foster closer ties with the region, in a movement that can be understood in the broader context of German trade as a shift away from Western Europe-North America and towards Eastern Europe-South America, as described by Braun (2003, p. 64). In the case of German-Brazilian trade, cotton would play a prominent role. While other products such as coffee beans continued to represent a significant share of Brazil's exports to Germany, cotton would be central to the trade partnership between the two countries from 1933 to 1938. Brazil became Germany's main supplier of cotton in these years, overtaking the United States with a share of 29.3 per cent of total German cotton imports (Seitenfus 2000, pp. 42-43).

Ritter was a pioneer in perceiving the potential benefits of securing trade partnerships between Brazil and Germany. In a memorandum from 1935, he pointed out the potential complementarity of the economic needs of Brazil and Germany, taking the lead in the negotiations of the new trade agreement between the two countries based on the directives of Schacht's New Plan (Seitenfus 2000, pp. 37-38). The memorandum echoed earlier reports on Brazilian productive necessities, in order to establish the amounts of various products to be exported to Germany in exchange, including cotton, tobacco and rubber, which Brazil sought to incorporate into the new trade agreement as negotiations began in 
FIGURE 1

TOTAL VALUE OF BRAZILIAN IMPORTS FROM THE USA, GERMANY AND GREAT BRITAIN, 1928-1939 (ABSOLUTE VALUES IN 1939 POUNDS-STERLING).

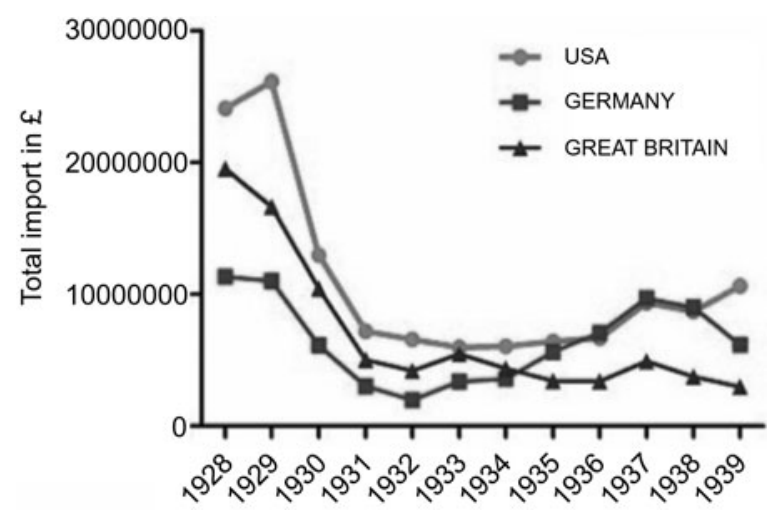

Source: IBGE. Anuário Estatístico do Brasil, 1939-1940, pp. 1366-1369.

$1934^{8}$. Following this early period of negotiations, Brazilian exports to Germany experienced an increase of approximately 60 per cent in the space of a month as soon as late $1934^{9}$.

Observing the success of the German-Brazilian partnership (see figure 1), Ritter engaged personally in the negotiations of a new trade agreement with Brazil. Despite the initial resistance by the Brazilian government and protests from the United States, Brazilian authorities agreed to sign a trade agreement with Germany complying with the directives of Schacht's New Plan, which included the adoption of a clearing clause favourable to Germany ${ }^{10}$. Following the establishment of the New Plan, compensation agreements such as this became an integral part of Germany's commercial policy. This approach towards international trade sparked criticism, in particular from the League of Nations, which declared in a report from 1936 that the clearing system was a makeshift with a number of drawbacks and that the Economic Committee «would welcome its disappearance» ${ }^{11}$.

\footnotetext{
${ }^{8}$ Anschluss an Telegramm Nr. 38. PAAA R 105.852. Oct. 20, 1934

9 German trade with South American nations. PAAA R 105852 Doc. H005937. Probably mid-1935.

10 According to Seitenfus (2000, pp. 38-40), the clearing clause determined that trade between Brazil and Germany would be paid with frozen marks, available as credit for Brazilian purchases in the German market. In the worst scenario, German trade with Brazil would become a zero sum.

11 Economic Committee of the League of Nations, Report to the Council on the Work of its Forty-fourth session. C.377.M.248. Sep. 12, 1936. Available at: http://biblio-archive.unog.ch/ Dateien/CouncilMSD/C-377-M-248-1936-II-B_EN.pdf
} 
As the specialist in economic affairs within the German Foreign Office, Ritter followed the debate closely, reacting to the report in an article commissioned by the journal Foreign Affairs and published in that same year. Originally intended for a special edition dedicated to Germany, the article outlined the reasons that, in Ritter's words, "forced» Germany to adopt clearing agreements as a standard practice. According to the text, the need for the establishment of compensation agreements emerged in 1931 as creditors, especially from the United States, began to withdraw their capital from the German market, severely reducing German foreign exchange reserves. Despite agreeing with the experts of the League of Nations that clearing and compensation agreements were not the most desirable practice, Ritter argued that this type of arrangement was a temporary necessity in order to preserve Germany's foreign exchange reserves and the supply of raw materials (Ritter 1936, pp. 466-473).

Ritter (1936, pp. 468-469) argued that there were two groups of nations with which Germany had secured trade agreements based on compensation. The first was composed of countries that had introduced exchange controls before Germany and the second comprised those which could afford an unchecked balance of trade. Brazil certainly fitted the description of the first group. Following the rise of President Getúlio Vargas, Brazil sought to centralise capital flows in and out of the country, responding to the exceptional situation created by the Great Depression ${ }^{12}$. As a consequence of the New Plan, Germany adopted a similar approach, centralising exchange control and reducing the autonomy of companies to select their providers of raw materials. German importing businesses, therefore, were forced to purchase from suppliers in countries with which Germany had clearing agreements, thus creating privileged commercial relations with these economies.

The adoption of clearing agreements marked an important change in Germany's trade policy. The focus on essential goods attributed greater importance to providers of raw materials, marking a shift in German trade partnerships away from Western Europe-North America towards Eastern Europe and South America. Examining German-Brazilian economic relations in this context, Hilton (1977, p. 85) associates the expansion of trade after 1934 to long-term German interests in the Brazilian market and to pre-existing commercial connections. In his view, the underlying aim of German trade policy was twofold: to achieve balance between imports and exports and to stimulate industry. The ultimate goal of this geographical shift, however, goes beyond the favourable balance of trade and the stimulus to the German economy. In the case of Eastern Europe, the Nazis sought to create a contiguous economic network of

\footnotetext{
${ }^{12}$ For the decree regulating this, see BRASIL, 1931.
} 
partners and allies (Braun 2003, p. 64). Although Brazil did not participate in this dimension of the Nazi project involving a European extended economic space, its role as an important supplier of raw materials to the economic reconstruction effort required the creation of a strategic commercial relationship to be enacted by the adoption of compensation trade.

The Brazilian need to respond to the plummeting prices of coffee and the decreasing participation of the United States in the national market in the early 1930s favoured Germany's attempt to incorporate Brazil into its portfolio of clearing partners. Negotiations were difficult, as Brazil presented numerous objections to the German proposals; however, with the support of Ritter, Brazil and Germany agreed on the terms of a new trade agreement in 1936. Ideological affinities between Hitler and sections of the Brazilian government further contributed to the good diplomatic atmosphere between the two countries until 1938 (Cervo and Bueno 2002, pp. 233-268). Ritter's crucial participation in the successful commercial negotiations made him a very appropriate candidate to preserve this strategic friendship prevailing between the two countries. Hence, he was appointed as Ambassador to Brazil in 1937.

The movements that culminated with Ritter's departure to Rio de Janeiro in 1937 were embedded in a broad strategy geared towards increasing Germany's autarky regarding the supply of inputs necessary to ensure the economic viability of the prevailing political project. The autarkic nature of this strategy meant that trade should be managed from the point of view of Germany's "own security», to use Heinrich Hunke's expression. The Brazilian economy was thus evaluated in terms of its capacity to provide raw materials considered functional to the maintenance of domestic economic performance. The next section examines how this strategy, confessedly underpinned by an antiliberal conceptualisation of international trade, informed the discourse of German diplomats serving in Brazil.

\section{GERMAN DIPLOMATIC DISCOURSE IN BRAZIL (1928-38)}

The early 1930s were difficult for the Brazilian economy. The country's virtual monopolistic position in the international coffee market had driven coffee plantations into a situation of overproduction that was aggravated by the global depression. In consequence, as coffee prices plunged, the external shock caused by the crisis disrupted the Brazilian balance of payments. The exported volume did not respond to the falling prices, nor did the capital account compensate for the losses, as foreign capital inflows came to a stop. There was a substantial decline in national income, yet this was relatively mitigated by the effects of coffee valorisation policies 
and the favourable performance of the emerging domestic industry (Abreu 1999, p. 74). This economic strain occurred in parallel with important political transformations that were not restricted to Brazil, but rather a global phenomenon associated with many regime shifts, as exemplified by the rise of fascism in Europe and of authoritarian regimes in Latin America (Hobsbawm 1995, pp. 90-143). In Brazil, with the 1930 Revolution and the rise of President Getúlio Vargas to power, new possibilities for political change emerged, as the hegemony of the coffee oligarchy was fractured.

This institutional rupture led to a political arrangement in which no dominant sector possessed the requirements to immediately establish its prominence. Hence, the early 1930s were years of instability, with different ideological projects disputing the direction of national economic policy. The international alignment of Brazil was also a matter of dispute in the Vargas administration, as advocates of an alliance with the United States coexisted with supporters of antiliberal projects who tended to side with fascist regimes such as those in Italy and Germany (Hilton 1977; Corsi 2000). The leading representative of the pro-U.S. wing of the government was Oswaldo Aranha, who held several important posts, such as Finance Minister (1931-34), Ambassador to the United States (1934-37) and Minister of Foreign Affairs (1938-44). The interruption of Karl Ritter's incumbency in Brazil was partly due to Minister Aranha's anti-Germanism. Among Germanophiles, there were high-ranking military officers such as Góis Monteiro, Defense Minister (1934-35) and a nationalist ideologue, and Eurico Gaspar Dutra, Defense Minister (1936-45) and successor of Vargas as Brazilian president. In general, it is possible to affirm that from 1930 until the definitive alignment with the Allies in the 1940s, the political environment in which German representatives operated in Brazil was a relatively favourable one.

German diplomats sent to Brazil in the 1930s were allocated in the capital, Rio de Janeiro, first as a Legation, later converted into an Embassy in 1936. As part of their normal duties, they had to report regularly to the internal division of the German Foreign Office in charge of Brazil (and most of Latin America), the so-called Department III. There, all the correspondence was examined, sorted by subject and relevance, then finally distributed to the assigned superior authority. In relevant cases some reports would even reach the office of Foreign Minister Konstantin von Neurath himself (Hürter and Mayer 2014). The most common and most broadlybased reports were the Politische Jahresübersichten (Annual Political Overviews) or Politische Jahresberichte (Annual Political Reports), normally elaborated at the beginning of the following year. Such reports, despite their names, included not only political, but also economic, social and statistical information. They were divided into sections, according to themes. Similar reports, with a more local character, were sometimes produced by the German consulates, located in important Brazilian cities 
other than Rio de Janeiro, such as São Paulo, Curitiba and Porto Alegre. Because of the regularity and scope of the information contained in these reports, representing the views of German diplomats and civil servants, they are important sources for an understanding of the place of Brazil in their economic discourse.

Another useful source is the Bericht der Deutsch-Brasilianischen Handelskammer (Annual Report from the German-Brazilian Chamber of Commerce), in which the perspective of some of the actors involved in commercial relations between Germany and Brazil is clearly expressed. As they were published in the German press and hence accessible to officers serving in the Foreign Office ${ }^{13}$, these reports show the construction and circulation of ideas regarding the place of Brazil in German economic and political projects. Furthermore, we drew on sources such as consular reports and other sorts of diplomatic correspondence produced by German diplomats in Brazil concerning their view of the economic relations between the two countries and on the German interests at stake.

As early as the beginning of 1929, the Legation's report concerning the year 1928 pointed to an important issue in German-Brazilian relations during the final years of the Weimar Republic. Brazilian exports to Germany had experienced, at the end of the 1920s and before 1929, a steady increase, while imports declined. In part, diplomats attributed this trade deficit to the record coffee production in that year, coupled with the policy of valorisation of Brazilian coffee, which was aimed at stabilising the price of coffee in the global market and in fact increased it. The report addressed this policy from a traditional free-trade perspective and also highlighted the virtual monopolistic position of Brazil in the international coffee market (about 77 per cent of the world's total production that year). Furthermore, it addressed the difficulties in exporting such a large volume of coffee and the dangers involved in increasing the already excessive production ${ }^{14}$. The valorisation measures were considered to be contrary to German interests. Although the harm to national interests was not specified in detail, it probably referred to the negative results of the German balance of trade with Brazil. In a context of domestic economic recession and scarcity of foreign currency to meet international financial commitments, trade deficits were a source of serious concern ${ }^{15}$.

13 As mentioned in the introduction to the Report on the Year 1935 (Bericht über das Jahr 1935. Deutsch-Brasilianischen Handelskammer)—Rio de Janeiro, 1935. Bundesarchiv R11/1256, pp. 109139.

${ }_{14}$ Politisches Jahresübersicht. PAAA R 91.715. Deutsche Gesandtschaft Rio de Janeiro to AA (Berlin). Jul/1929. p. 4.

15 Politisches Jahresübersicht. PAAA R 91.715. Deutsche Gesandtschaft Rio de Janeiro to AA (Berlin). Jul/1929. p. 4. 
In the following year, the focus of the report was the global economic crisis that was disrupting the trade flows between the two countries and the measures regulating coffee prices. The author of this report draws particular attention to the devaluation of the Brazilian currency and its effects on imports from Germany. The general concern was the reestablishment of the pre-crisis status of the world economy, as well as the preservation of the international gold standard. As in the previous report, the discourse was marked by a classical liberal tone ${ }^{16}$. The same problems were again briefly described in the report concerning the year 1930, albeit with a clearer understanding that the crisis had a depth and scope hitherto unseen ${ }^{17}$. In an appendix to the Annual Report of 1931, titled «Economic Review for the year 1931», a critique of the coffee valorisation policy is overtly presented, with special emphasis on the ineffectiveness of the measures. The main point of criticism was that such policies distorted prices, as these were artificially kept above those correspondent to market conditions, thereby reinforcing excessive production. This would have disruptive consequences for the entire Brazilian economy:

[...] the export of the national produce of coffee will not grow, because the demand of the world market is limited, while Brazil, because of its current customs and economic policies, is incapable of producing at world-market prices, [therefore] the solution to the whole national economic problem stays dependent on the coffee question. [...] a sustainable improvement would only be successful when the root of the problem is addressed, [not] allowing for excessive growth of coffee plantations ${ }^{18}$.

The reports issued after the year 1933, however, had a rather different tone. Sent to the Foreign Office the day after the nomination of Hitler as Chancellor of the Reich (30 January 1933), the first report after the Nazi seizure of power had only minor references to economic matters. It focused mainly on the political situation in Brazil, after the 1932 Revolution in the state of São Paulo, a regionalist uprising that, with the support of the local elites and military forces, posed a serious threat to the authority of the provisional central government, led by President Vargas. The report also alluded to the improvement of cultural relations

16 Politische Jahresübersicht: 1929. PAAA R 91.715 Deutsche Gesandtschaft to AA. Feb/1930. p. $4-5$.

${ }^{17}$ Politische Jahresübersicht: 1930. PAAA R 91.715 Deutsche Gesandtschaft to AA. Feb/1931. p. 4-5.

18 Wirtschaftlische Übersicht für 1931. PAAA R 91.715 Deutsche Gesandtschaft to AA. Mar/ 1932. p. 11 
and mentioned the expectations of continued good relations with the new German government ${ }^{19}$.

In 1933, diplomatic communication was not restricted to this more political report written in January. In May of the same year, a supplement was issued by the German General Consulate in São Paulo, dealing exclusively and in detail with economic matters. In this document, the coffee policy adopted by the Brazilian government, which consisted of buying the excessive supply (the term used in German was «Überangebot») of coffee was praised. It would, according to the diplomats in charge of the report, help the "reestablishment of a market which is the general barometer of the economy», bringing an increase in the profits of coffee planters and thus reducing unemployment. For the first time in these diplomatic reports, an element of state intervention in the economy was viewed in a positive light. The prosperity of the local industrial sector was also underlined as strategic, as it accounted for a general increase in the Brazilian imports of manufactured inputs, many of which were not available in the domestic market. Despite the «bad fiscal and monetary situation» of the government of the state of São Paulo, the local ongoing events were seen to be interesting to German manufacturers ${ }^{20}$.

The same supplement also contained noteworthy comments on the idea that the economy of São Paulo should be redirected from the current coffee-based monoculture to a more diversified type of rural production, in order to overcome the crisis. Special emphasis was given to the possibility of expanding cotton plantations. According to the diplomats, the low profitability of coffee production, coupled with the decrease in the international prices of this commodity because of the global crisis, would present a great opportunity for the expansion of the cultivation of cotton. This would have a strategic character, as it could help meet the German demand for cotton.

[...] the crisis of coffee and the growing hardship faced by the planters led to a change, as the planters allowed their workers to maintain their own smaller cultures [...], [then] comes the cotton plantation, that should now be supported by the secretary of agriculture with the delivery of first class seeds. [...] [That] would lead to a full-valued product, a huge progress, not only quantitative, but especially in terms of quality ${ }^{21}$.

\footnotetext{
19 Politische Jahresübersicht: 1932. PAAA R 91.715 Deutsche Gesandtschaft to AA. Jan/1933.

20 Wirtschaftsübersicht: 1933-São Paulo. PAAA R 91.715 Deutsche General Consulat São Paulo to AA. May/1934. p. 2-11

21 Wirtschaftsübersicht: 1933-São Paulo. PAAA R 91.715 Deutsches Generalkonsulat São Paulo to AA. May/1934. p 12
} 
This emphasis is interesting because São Paulo had never before been a particularly important cotton supplier to the German market. Nonetheless, as described in the previous sections, a declining trend in international trade and the limited access to traditional supplying sources made the possibility of establishing closer ties between Germany and Brazil relatively more attractive. The proposal to enhance the production of cotton meant that the economy of São Paulo would play a strategic role in the economic space under German influence and thus contribute to its project of power. Indeed, Brazil would overtake the United States and become the premier supplier of cotton for German industry by 1938 .

The 1935 Report from the German-Brazilian Chamber of Commerce compliments the "measures taken to increase trade between both nations», clearly referring to the informal agreement on clearance trade, signed in 1934. The author of the document notes "with satisfaction, that the South-American market, especially Brazil, is increasingly important for Germany». Especially interesting for the case in point is the fact that the document dedicates the whole of a long section to cotton trade, relating this particular kind of export with German «national interests», given the need for a reliable source of raw materials for German textile industry ${ }^{22}$. By the same token, the Chief of the German Legation in Brazil, Schmidt-Elskop, sent a telegram to the Foreign Office in June 1935, reporting pressure from German firms in the Brazilian press for the alleviation of currency restrictions concerning products "other than cotton», affected by currency control operations carried out by the Brazilian national bank. Elskop summarily says that measures could be taken to respond to such complaints, "however without affecting the defense of this important German interest [cotton trade]» ${ }^{23}$.

The Legation/Embassy in Rio de Janeiro, as well as the General Consulates of Germany in major Brazilian cities generated specific reports on products. Reports on the evolution of cotton production in São Paulo, for example, reveal a difference in discourse between the 1931 "Cotton Report» of the Consulate in São Paulo ${ }^{24}$ and another Report on cotton, produced in 1935. While the 1931 document stresses the diversification of the state's production as a sound economic strategy to face the crisis, as it involved reaching a potentially broader international market, the 1935 Report emphasises the fact that it would be important to take measures to maintain the supply of cotton to Germany in the face of a potential increase of Brazilian exports to other countries, such as England and Japan ${ }^{25}$.

22 Report on the Year 1935 (Bericht über das Jahr 1935. Deutsch-Brasilianischen Handelskammer)—Rio de Janeiro, 1935. Bundesarchiv R11/1256, pp. 128-131.

23 Telegram Schmidt Elskop to AA. PAAA R 244.642. Rio de Janeiro, 06/17/1935.

${ }^{24}$ Baumwollbericht 1931 PAAA R 246.536. São Paulo, 11/25/1931.

25 Baumwollbericht PAAA R 246.536. São Paulo, 04/01/1935. 
As for rubber, it is also relevant to contrast documents from before and after 1933. The first, an attachment to a Report sent by the Legation in Rio de Janeiro to the German Foreign Office, at the end of 1926, discusses the "Possibilities for Germans in the Amazon Region», referring to products related to the "Colonial Economy» in Brazil. In this document, the monopoly of rubber plantations by a few firms is criticised and the author defends a more open access to such trade ${ }^{26}$. The second, a message sent by the Legation to the Foreign Office's Ministerial Director, Dr Kiep, in April 1935, discusses the economic problems faced by a rubber producing company (Behringer \& $\mathrm{Cia}$ ). Both the diplomatic missive and an attached letter, sent by Behringer to the Legation, stress the «importance of guaranteeing the supply of rubber to Germany», which would be threatened by «the interests awaken by American and local speculators, who perturbed it».

Also attached to that missive is an excerpt from the Brazilian newspaper Diário do Estado, dated 21 March 1935, which states that the «German trade ambassador», Harold Fehrman, had expressed the "satisfaction of German industrial leaders with the creation of the Institute of Nuts and Rubber», that same year. The newspaper also emphasises the "plans of the Germans to acquire the entirety of Brazil's rubber production». In a brief commentary attached in a separate leaflet, Schmidt-Elskop highlights the absurdity of such claims by the newspaper, but he comments that it could be of great interest to secure rubber supplies from Brazil, if the prices of rubber were not pushed so high by speculators as demand was increasing in Germany. The Legation would then, according to Elskop, verify which measures it could possibly take to neutralise such speculation ${ }^{27}$.

Similar topics were explored in a letter sent to Karl Ritter by a German representative who was part of a delegation sent on a mission to Latin America in July 1934. As shown above, by this time Ritter was in charge of the Economic Policy Department of the Foreign Office. This letter dealt with the difficulties met in the negotiations of Clearance Trade deals with Brazil and Argentina. In face of the persistency with which, according to the author, Brazilian authorities defended the maintenance of coffee exports outside general restrictive quotas, the representative disagreed with this notion and argued that coffee («a non-essential good, given that it's not necessary for life») should actually be included in the restrictions. In exchange for the eventual limitation of the German absorption of Brazilian coffee, he advocated an increase in other Brazilian exports more suitable to German interests, such as cotton and rubber.

26 Anschluss mit Beziehung auf den Bericht 4602/26. PAAA 247.253. Rio de Janeiro, 12/30/1926.

27 Letter from the German Legation in Rio de Janeiro to Kiep. PAAA R 246.538. Rio de Janeiro, $04 / 12 / 1935$. 
The letter also emphasised how Brazil seemed to be a more promising partner than Argentina and other Latin American countries, given the resistances experienced for each case ${ }^{28}$.

As demonstrated in the examples above, the rupture between the Weimar Republic and National Socialism was reflected in the rapid change in the discourse about Brazil produced within the Foreign Office. From 1934 to 1936, the main objects of discussion were related to the Bilateral Trade Agreements, based on the clearance concept. Furthermore, special attention is given to the negotiations and eventual signature of a Trade Agreement between Brazil and the United States in February 1935, which incorporated liberal and multilateral clauses and was, therefore, considered contrary to German interests regarding Brazil. The ideas mobilised referred to the importance of maintaining the channel of trade with Brazil, even against American pressures. Hence, the necessity of a formal clearance agreement was challenged and a more «informal agreement» (as it was actually signed) was defended, as it could more easily maintain the German-Brazilian trade channel open. The arrangement was supposed to «keep the German economy more independent from external pressure ${ }^{29}$. This justification for securing the commercial bonds between Brazil and Germany reflected the idea that Brazil should function as an important piece in a German extended economic space, since the proximity with this country was seen to protect Germany from «external» pressure. Although they were not directly mentioned in the reports, the war preparations became more and more the background against which these negotiations took place, especially from 1936 onwards (Overy 1995, p. 177ff).

The discussions involving trade agreements in the 1930s affected not only the interests of the global powers in Brazil, but also prompted reactions from domestic interest groups (Lima 2013). The most resounding opposition to the U.S.-Brazil Trade Agreement of 1935 came from industrialists, who complained that opening the Brazilian market to American products would thwart the progress of the domestic manufacturing sector. It is worth noting that this industrialist objection to the U.S.-Brazil Trade Agreement of 1935 eventually drew on theoretical arguments attuned with German lineages of economic thought that conceptualised autarky in the $19^{\text {th }}$ century. The prominent leader of the Brazilian industrial bourgeoisie and federal deputy Roberto Simonsen overtly mentioned the «German teachers» Karl Rodbertus and Adolph Wagner, as authorities who had a more suitable approach to international trade for Brazil than the free-trade doctrine. Simonsen did not mention the word «autarky» in his parliamentary interventions against the Treaty, but he did praise the nationalist

\footnotetext{
28 Letter to Karl Ritter. PAAA R 246.536 (reproduced in R 246.538). Buenos Aires, 06/24/1934.

29 Politischer Jahresbericht: 1935. PAAA R 104.939 Deutsche Botschaft to AA, 1936.
} 
conceptualisation of «national economy», as proposed by Wagner (Bruzzi Curi and Lima 2015, pp. 483-489).

The analysis of the discourse of German diplomats, as expressed in the reports issued between 1933 and 1936, leads to the recognition of the general framework of economic thinking that informed their understanding of Brazil and of the country's place in German foreign policy. It was regarded not only as a mere partner in mutually beneficial bilateral relations, but in fact as an important piece in the constitution of a German sphere of economic interest in South America. The purpose of opposing American hegemony in the region, as well as the firm willingness to secure access to a source of strategic raw materials, illustrate a geopolitical stance and a corresponding economic discourse attuned to an idea of autarky, in the sense of guaranteeing the supply of necessary inputs. This network of secure suppliers to the German markets was supposed to be under some degree of German economic influence. So the appointment of economic expert Karl Ritter, who arrived in Rio de Janeiro to take office as German Ambassador in June 1937, can be regarded as the culmination of the attempt to integrate Brazil into such geopolitical projects by means of strategic trade arrangements.

At the end of the timeframe of our analysis, the focus of the reports shifts remarkably. In the Annual Reports for 1937 and 1938, the reference to strictly economic matters was considerably reduced. There were general references to the situation of the economy and tables, statistics of trade and very little in the way of the previously abundant observations on trade and economic relations. A lot of attention was given to the "persecution» of communities of German immigrants in the south of Brazil and attacks against Germany in the Brazilian media. When referring to economic matters, however, diplomats and officials made efforts to maintain the channels open. At that time more than ever it was necessary to secure the supply of strategic inputs, since war preparations were by then well under way. Germany was rapidly becoming a true "war economy», so that "national economic interests» were directly related to the capacity to be autarkic and to extend the «natural economic space» ${ }^{30}$.

This virtual absence of economic observations in the reports seems to be connected to two factors that affected German-Brazilian foreign relations at the end of the 1930s. On the one hand, there were the difficulties of sustaining clearance trade from 1937 onwards, in the face of growing opposition of the United States and Britain. On the other hand, there was the internal political scenario in Brazil. The new authoritarian regime instituted in 1937-Estado Novo, the «New State»-was suspicious of the

${ }^{30}$ Politischer Jahresbericht: 1937. PAAA R 27.196 Deutsche Botschaft to AA. Jan/1938 and Politischer Jahresbericht: 1938. PAAA R 27.196 Deutsche Botschaft to AA. Fev/1939. 
political activities of Germans in Brazil, particularly in the southern states which concentrated most of the German ethnic communities. The accusations against fifth column activities began to gain ground as early as the first months of 1937 and culminated with a set of laws presented between March and April 1938, restricting the participation of ethnic Germans in the political and economic life of the country (Gertz 1987; Dietrich 2007; Schulze 2016). The persecution of «the German element» in Brazil led to vehement protests by Ambassador Karl Ritter that ultimately resulted in his expulsion in September 1938.

The ensuing normalisation of diplomatic relations from 1939 until 1942 is not within the scope of this study, but, in brief, it is possible to indicate that the positive trend in trade reversed and the strategy of commercially integrating Brazil into an extended German economy, envisioned and practiced from 1933 to 1938, proved to be limited. The Brazilian drift towards the Allies is illustrated by the fact that, after long negotiations from 1938 to 1941, the United States prevailed as the source of financial and technical support for the development of the heavy steel industry in Brazil. Responding to American pressure, the definitive rupture of diplomatic relations came in January 1942, followed by the Brazilian declaration of war in August.

\section{FINAL REMARKS}

In the current study, we explored the interrelationship between the economic concepts of autarky and extended economic space, which have themselves a long historical development, and the strategic role played by Brazil in German foreign economic policy in the 1930s. The historical constitution of the concepts of Autarkie and Großraumwirtschaft was thus examined against the background of the $19^{\text {th }}$-century German intellectual tradition. We retraced the semantic trajectory of the concept of autarky, from an original meaning of self-sufficiency towards an expansionist connotation related to the conquest of secure suppliers of inputs. The "economic space» configured by this network of secure sources would constitute the German «economy of the extended space», or Großraumwirtschaft. In the context of the interwar years, marked by the disruptive effects of the world economic crisis and by the ascension of National Socialism, this conceptual apparatus was conveniently mobilised in order to tackle some of Germany's relevant economic issues. Particularly, it informed the formulation of German economic foreign policy in these years, for which Brazil was a strategic country.

The appointment of an economic expert, Karl Ritter, as Ambassador to Brazil in 1937 evinces the strategic commercial role that this South American power was supposed to play within the general goal of 
expanding the international sphere under German economic influence. His discourse emphasised Brazil's importance as a supplier of raw materials, pointing not only to the extraordinary increase in German-Brazilian trade, but also to the supposed ideological affinities between Hitler and sections of the Brazilian government. In his article published in 1936 by Foreign Affairs, he presented elements of the aforementioned conceptual framework, using ideas related to the autarkic way of conceptualising international trade.

These ideas integrated the economic discourse of German diplomats in Brazil. They were part of the framework of economic thinking that these diplomats had in mind as they sought to understand and interpret the Brazilian economic situation from the perspective of perceived «German interests». In the Annual Reports prepared in Brazil and sent to the German Foreign Office, it is possible to recognise the concrete formulation of recommendations that envisaged a deeper integration of Brazil into the sphere of German economic influence. The proximity with Brazil was seen to be desirable as it kept Germany immune to «external pressure». Furthermore, the encouragement of Brazilian cotton exports to Germany indeed reveals how the conceptual framework intertwined with economic policy and the flows of trade. The investment in a German-Brazilian economic partnership in the 1930s can thus be seen as a situation in which a specific, antiliberal conceptualisation of trade, expressed by ideas such as Autarkie and Großraumwirtschaft, was «applied» and acquired concrete shape.

\section{ACKNOWLEDGEMENTS}

Received 23 October 2017. Accepted 23 January 2019.

This research was supported by FAPESP - São Paulo Research Foundation (Brazil), the National Council for Scientific and Technological Development (CNPq/Brazil), CAPES, Brazil and the German Academic Exchange Service (DAAD/Germany). We are grateful for the helpful and attentive discussion of our manuscript by our colleagues at the Lateinamerika-Institut of the Free University of Berlin, especially Stefan Rinke. We also thank Alexandre Saes, Pedro Hoeper and Ricardo Streich for carefully reading and discussing the draft in our meetings at the Faculty of Economics, University of

São Paulo. The usual disclaimers apply.

\section{SOURCES AND OFFICIAL PUBLICATIONS}

AUSWÄRTIGES AMT. Deutsche Gesandtschaft/Botschaft, Rio de Janeiro. Politische Jahresberichte. (1928-1938). [GERMAN FOREIGN OFFICE. German Legation/ Embassy, Rio de Janeiro, Political Reports (1928-1938)] 
AUSWÄRTIGES AMT. Deutsches Generalkonsulat in São Paulo. Wirtschaftsübersicht: 1933. [GERMAN FOREIGN OFFICE. German General Consulate in São Paulo. Economic Overview: 1933]

AUSWÄRTIGES AMT. Deutsches Generalkonsulat in São Paulo. Baumwolleberichte: 1931-1935. [GERMAN FOREIGN OFFICE. German General Consulate in São Paulo. Cotton Reports: 1931-1936]

AUSWÄRTIGES AMT. Deutsche Gesandtschaft/Botschaft, Rio de Janeiro. [GERMAN FOREIGN OFFICE. German Legation/Embassy, Rio de Janeiro]. Letters and correspondence: 1928-1938.

DEUTSCH-BRASILIANISCHE HANDELSKAMMER Bericht über das Jahr 1935 [CÂMARA DE COMÉRCIO GERMANO-BRASILEIRA: Relatório sobre o ano de 1935].

BRASIL. Decreto 20.451, de 28 de setembro de 1931. [BRAZIL. Decree 20.451, September 28, 1931]

LEAGUE OF NATIONS, Economic Committee, Report to the Council on the Work of its Forty-fourth session. C.377.M.248. Sep. 12, 1936. Available at: http://biblio-archive. unog.ch/Dateien/CouncilMSD/C-377-M-248-1936-II-B_EN.pdf

IMT. International Military Tribunal. Trials of War Criminals: the ministries case, vol. XIII. Nuremberg: 1946-1948.

\section{REFERENCES}

Abreu, M. P. (1999): O Brasil e a economia mundial, 1930-1945: políticas econômicas externas e relações econômicas internacionais. Rio de Janeiro: Civilização Brasileira.

BarkaI, A. (1977): Das Wirtschaftssystem des Nationalsozialismus. Der historische und ideologische Hintergrund 1933-1936. Köln: Verlag für Wissenschaft und Politik.

Braun, H. J. (2003): The German Economy in the Twentieth Century: The German Reich and the Federal Republic. London: Routledge.

Bruzzi Curi, L. F., and Lima, D. B. M. (2015): «Roberto Simonsen and the Brazil-U.S. Trade Agreement of 1935: Economic Ideas and Political Action», Nova Economia 25(3), pp. 477-500.

Bruzzi Curi, L. F., and SAES, A. M. (2015): «Cuestionando las ortodoxias: Roberto Simonsen y Wladimir Woytinsky en el ambiente intelectual del período de entreguerras». Investigaciones de Historia Económica 11(3), pp. 141-152.

Cervo, A., and Bueno, C. (2002): História da política exterior do Brasil. Brasília: Editora UnB.

ConsI, F. (2000): Estado Novo: política externa e projeto nacional. São Paulo: Ed. Unesp.

Dietrich, A. M. (2007): «Nazismo Tropical? Partido Nazista no Brasil». Universiade de São Paulo, PhD Diss.

Eulenburg, F. (1932): Großraumwirtschaft und Autarkie. Jena: Fischer.

Evans, R. (2003): The Coming of the Third Reich. New York: Penguin Press.

Gertz, R. (1987): O fascismo no sul do Brasil. Porto Alegre: Mercado Aberto.

Gourevitch, P. (1986): Politics in Hard Times. London: Cornell University.

Heilmann, M. (1980): Adolph Wagner - ein deutscher Nationalökonom im Urteil der Zeit. Probleme seiner theoriegeschichtlichen Würdigung im Lichte neuer Quellen. Frankfurt/New York: Campus Verlag.

Hilton, S. (1977): O Brasil e as grandes potências: os aspectos políticos da rivalidade comercial, 1930-1939. Rio de Janeiro: Civilização Brasileira.

Hobsbawm, E. (1995): Era dos extremos: o breve século XX. São Paulo: Companhia das Letras. 
Hunke, H. (1934): «Die Lage», Die deutsche Volkswirtschaft. Nr. 16, 1. Juniheft, 3. Jahrgang, 1934.

Hürter, J., and Mayer, M. (2014): Das Auswärtige Amt in der NS-Diktatur. Oldenbourg: De Gruyter.

Jacobsen, H.-A., and Smith, A. L. (2012): The Nazi Party and the German Foreign Office. New York: Routledge.

Kershaw, I. (2010): The Nazi Dictatorship: Problems \& Perspectives of Interpretation. London: Bloomsbury.

KoselLeck, R. (1989): Vergangene Zukunft: zur Semantik geschichtlicher Zeiten. Frankfurt am Main: Suhrkamp.

KRÜGER, P. (1984): "Changing Structures of the German Foreign Office between the World Wars», in Opinion publique et politique extérieure en Europe. II. 1915-1940. Actes du Colloque de Rome (16-20 février 1981). Rome: École Française de Rome, pp. 139-156.

Lima, D. B. M. (2013): «A conformação dos grupos de interesse no debate sobre o Tratado de Comércio Brasil-Estados Unidos (1935)», História econômica \& História de empresas 16(2), pp. 247-267.

Mazzucchelli, F. (2009): Os Anos de Chumbo: Economia e politica internacional no entreguerras. São Paulo: Editora da UNESP.

Mitchell, N. (1999): The Danger of Dreams: German and American Imperialism in Latin America. Chapell Hill: The University of North Carolina Press.

NSDAP (1932): Wirtschaftliches Sofortprogramm der NSDAP. 2nd edn. München: Eher.

Noakes, J., and Pridham, G. (1998): Nazism 1919-1945. Vol. 1. The Rise to Power 19191934. Exeter: University of Exeter Press.

Overy, R. (1995): War and Economy in the Third Reich. Oxford: Oxford University Press.

Petzina, D. (1968): Autarkiepolitik im Dritten Reich. Der nationalsozialistische Vierjahresplan. Stuttgart: Deutsche Verlags-Anstalt.

Rabe, H. (1972): «Autarkie», in O Brunner, W. Conze, and R. Koselleck (eds), Geschichtliche Grundbegriffe. Bd. 1. Stuttgart: Klett-Cotta, pp. 377-381.

Rathenau, W. (1913): «Deutsche Gefahren und neue Ziele», in W. Rathenau (ed.), 1925 Gesammelte Schriften. Bd. 1. 31. Auflage. Berlin: Fischer, pp. 267-278.

Ratzel, F. (1901): «Der Lebensraum. Eine biogeographische Studie», in K. Bücher, V. Fricker, F. X. Funk, G. Mandry, G. Mayr, F. Ratzel. Festgaben für Albert Schäffle zur Siebensigen Wiederkehr Seines Geburtstages am 24. Februar 1901. Tübingen: Laupp.

RichteR, M. (1990): «Reconstructing the History of Political Languages: Pocock, Skinner, and the Geschichtliche Grundbegriffe», History and Theory, 29(1), pp. $465-475$.

RitTER, K. (1936): «Germany's Experience with Clearing Agreements». Foreign Affairs (14).

RuHLand, G. (1894): «Zur Agrarfrage», Jahrbücher für Nationalökonomie und Statistik, 3. Folge, Bd. 7.

Schäffle, A. (1896): Bau und Leben des sozialen Körpers. 2. Aufl. 2. Band («Specielle Sociologie»). Tübingen: Laupp.

Schmoller, G. (1900): "Die wirtschaftliche Zukunft Deutschlands und die Flottenvorlage», in G. Schmoller (Hrsg.). Handels- und Machtpolitik. Bd. 1. Stuttgart: Cotta, pp. 1-38.

Schulze, F. (2016): Auswanderung als nationalistisches Projekt. Köln: Böhlau Verlag.

Seitenfus, R. (2000): A entrada do Brasil na Segunda Guerra Mundial. Porto Alegre: EDIPUCRS. 
Sмiтн, W. (1980): «Friedrich Ratzel and the Origins of Lebensraum», German Studies Review 3(1).

Sombart, W. (1932): Die Zukunft des Kapitalismus. Berlin: Buchholz \& Weißwange.

Teichert, E. (1984): Autarkie und Großraumwirtschaft in Deutschland 1930-1939: außenwirtschaftspolitische Konzeptionen und Zweiter Weltkrieg. München: Oldenbourg.

Tooze, A. (2006): Wages of Destruction: The Making and Breaking of the Nazi Economy. New York: Viking.

TRIBE, K. (1995): Strategies of Economic Order: German Economic Discourse 1750-1950. Cambridge: Cambridge University Press.

Wehler, H.-U. (2008): Deutsche Gesellschaftsgeschichte. Dritter Band: Von der «Deutschen Doppelrevolution» bis zum Beginn des Ersten Weltkrieges. München: C.H. Beck. 